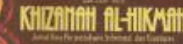

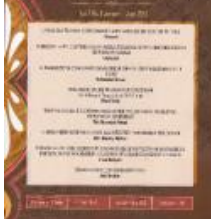

\section{Pemanfaatan Jurnal Elektronik oleh Mahasiswa Fakultas Kedokteran Universitas Hasanuddin Makassar}

Harisyah*, Muhammad Azwar**

Pengutipan: Harisyah, \& Azwar, M. (2014). Pemanfaatan jurnal elektronik oleh mahasiswa Fakultas Kedokteran Universitas Hasanuddin Makassar. Jurnal Ilmu Perpustakaan, Informasi, dan Kearsipan Khizanah Al-Hikmah, 3(1), 79-88. Diambil dari http://journal.uinalauddin.ac.id/index.php/khizanah-al-hikmah/article/view/588

* Alumni Jurusan Ilmu Perpustakaan UIN Alauddin Makassar (harisyahanafi@gmail.com)

** Dosen Jurusan Ilmu Perpustakaan UIN Alauddin Makassar (muh.azwar@uin-alauddin.ac.id)

\title{
ABSTRAK
}

Jurnal merupakan referensi yang paling sering digunakan sebagai dasar dalam melakukan penelitian di perguruan tinggi, karena materi-materi yang dipublikasikan merupakan materi terkini dan merupakan hasil temuan atau hasil penelitian. Pada saat sekarang ini, munculnya jurnal elektronik mengakibatkan perpustakaan lebih memilih untuk berlangganan jurnal elektronik dibanding dengan media cetak. Hal ini dikarenakan jurnal elektronik lebih mudah diakses dibandingkan dengan jurnal cetak. UPT Perpustakaan Universitas Hasanuddin merupakan salah satu perpustakaan perguruan tinggi yang melanggan jurnal elektronik. Akan tetapi, jurnal elektronik yang dilanggan oleh UPT Perpustakaan Universitas Hasanuddin belum dimanfaatkan secara merata oleh mahasiswa khususnya Mahasiswa Fakultas Kedokteran Universitas Hasanuddin. Mahasiswa tidak memanfaatkan jurnal elektronik tersebut bukan dikarenakan mereka tidak membutuhkan jurnal elektronik yang telah dilanggan. Akan tetapi, sebahagian besar dari mahasiswa belum mengetahui adanya jurnal elektronik yang telah dilanggan oleh UPT Perpustakaan Universitas Hasanuddin.

Kata Kunci: jurnal elektronik, Mahasiswa Fakultas Kedokteran UNHAS

\section{ABSTRACT}

Journal is one of information forms. It is often used as a primary source to research, mostly in higher education. Journal, as many defined it, consists of contemporary thoughts and knowledge, and research findings as well. Nowadays, electronic journals are considered as the main option for many higher institutions to subscribe compared to its printed form. It is due to the easiness and accessable usage. UPT Perpustakaan Hasanuddin (Hasanuddin University Library) is one of those academic libraries that has been subscribed electronic journals. Nevertheless, those electronic journals were lack of usage by degree medical students. The main reason was the lack of promotion or dissemination by the library.

Key Words: electronic journal, degree students of Faculty of Medicine UNHAS 


\section{PENDAHULUAN}

\section{a. Latar Belakang Masalah}

Peraturan Pemerintah Republik Indonesia Nomor 24 tahun 2014 tentang Pelaksanaan Undang-undang Nomor 43 Tahun 2007 tentang Perpustakaan yang secara garis besar menjelaskan bahwa Perpustakaan Perguruan Tinggi adalah Unit Pelaksana Teknis (UPT) yang merupakan bagian integral dari kegiatan pendidikan, penelitian dan pengabdian kepada masyarakat dan berfungsi sebagai pusat sumber belajar untuk mendukung tercapainya tujuan pendidikan yang berkedudukan di perguruan tinggi (Republik Indonesia, 2014: 3).

Di era teknologi informasi saat ini, publikasi karya ilmiah dalam bentuk online merupakan cara yang paling mudah dan dapat menjangkau semua lapisan masyarakat yang ada. Sebagai contoh jurnal ilmiah yang biasanya disediakan oleh lembaga-lembaga pendidikan, khususnya pendidikan tinggi.

Banyak universitas yang ada saat ini memiliki atau berlangganan jurnal-jurnal ilmiah, baik dalam maupun luar negeri yang memang disadari akan pentingnya keberadaan jurnal-jurnal tersebut.

Jurnal elektronik yang memiliki reputasi tinggi biasanya menyediakan kandungankandungan informasi yang berkualitas dan terpercaya. Namun tidak sedikit juga jurnal yang ada, khususnya yang tidak terkelola dengan baik menyediakan informasi yang kurang baik dan memiliki tingkat validitas dan kepercayaan yang rendah atau juga menawarkan kandungan informasi yang tidak kontemporer.

Berkaitan dengan paragraf di atas, dalam Surah Al-Hujarat (49:6), Allah swt berfirman:

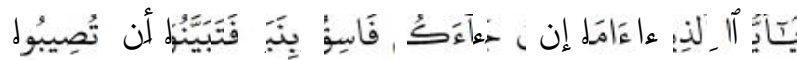

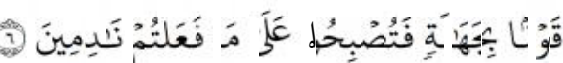

yang terjemahnya :

Hai orang-orang yang beriman, jika datang kepadamu orang fasik membawa suatu berita, maka periksalah dengan teliti agar kamu tidak menimpakan suatu musibah kepada suatu kaum tanpa mengetahui keadaannya yang menyebabkan kamu menyesal atas perbuatanmu itu.

Kehidupan manusia dan interaksinya haruslah didasarkan hal-hal yang diketahui dan jelas. Manusia sendiri tidak bisa menjangkau seluruh informasi, karena itu ia membutuhkan pihak lain. Pihak lain itu ada yang jujur dan memiliki integritas sehingga hanya menyampaikan hal-hal yang benar dan ada pula sebaliknya. Karena itu pula berita harus disaring, dikhawatirkan jangan sampai seseorang melangkah tidak dengan jelas atau dalam ayat di atas disebut bijahaalah yang berarti kebodohan (Shihab, 2002: 128).

Teknologi informasi dan komunikasi yang berkembang pesat telah membawa dampak yang begitu besar terhadap berbagai bidang kehidupan, tidak terkecuali Perpustakaan Perguruan Tinggi. Perpustakaan Perguruan Tinggi harus bisa memenuhi berbagai kebutuhan informasi para pemustakanya.

Perpustakaan Perguruan Tinggi tidak hanya memberikan layanan yang sama dari tahun ke tahun namun harus menyesuaikan dengan perubahan kebutuhan pemustaka, diawali dari perpustakaan manual, perpustakaan terotomasi sampai kepada perpustakaan digital. Jika tidak mengikuti perkembangan tersebut, perpustakaan akan ditinggalkan pemustakanya.

Perkembangan sebuah perpustakaan tidak lagi diukur dengan skala luas gedung, jumlah koleksi yang tersedia maupun jumlah pengunjung yang datang ke perpustakaan. Akan tetapi, sekarang ini sebuah perpustakaan dikatakan sebagai sebuah perpustakaan yang maju dapat diukur dari penerapan teknologi informasi yang digunakan. Penggunaan teknologi informasi pada perpustakaan akan mempermudah pertukaran informasi, sehingga penyebaran 
pengetahuan menjadi begitu cepat (Supriyanto, 2012: 13).

Koleksi perpustakaan saat ini pun ramai diisi dengan koleksi-koleksi dalam format elektronik. Adapun koleksi yang dimaksud dalam penelitian ini adalah jurnal elektronik yang termasuk dalam salah satu kategori sumber rujukan/referensi. Jurnal merupakan koleksi perpustakaan yang menyajikan informasi mutakhir dan berperan strategis dalam perkembangan ilmu pengetahuan. Jurnal dapat dikatakan sebagai media paling efektif untuk menyampaikan informasi. Selain itu, jurnal juga tergolong sebagai salah satu kelompok literatur primer karena informasi yang terkandung di dalamnya merupakan informasi orisinil yang berupa ide, gagasan maupun pengalaman seseorang.

Jurnal merupakan referensi yang paling sering digunakan sebagai dasar dalam melakukan penelitian di perguruan tinggi, karena materi-materi yang dipublikasikan merupakan materi terkini dan merupakan hasil temuan atau hasil penelitian. Jurnal juga merupakan media bagi civitas akademika dalam meningkatkan kemampuan dalam hal pengembangan keilmuan. Jurnal ini dapat diperoleh salah satunya di perpustakaan. Oleh karena itu, adanya jurnal ilmiah menjadi media yang perlu dimiliki oleh perpustakaan Perguruan Tinggi (Widi, 2010: 38-39).

Munculnya publikasi jurnal elektronik menggeser peran jurnal dalam media cetak yang dianggap terlalu lama dan membutuhkan biaya yang besar dalam hal penerbitan dan pemanfaatannya (Prahastuti, 2006: 29). Jurnal versi elektronik memiliki informasi yang lebih mutakhir dan dapat diakses cepat oleh para ilmuwan atau peneliti dalam menunjang kegiatan penelitiannya. Selain itu, jurnal versi elektronik mempunyai banyak keunggulan dibandingkan dengan jurnal dalam versi cetak. Keunggulan tersebut antara lain:

1) Bagi pihak penerbit dapat disebarkan lebih ekonomis
2) Bagi perpustakaan dapat menghemat biaya pemeliharaan

3) Bagi para penulis dapat mengurangi panjangnya waktu atau proses penerbitan naskah atau dapat menghindari penundaan terbitan akibat terbatasnya ruang jurnal (Adriaty, 2006:26).

Keunggulan-keunggulan jurnal versi elektronik inilah yang kemudian menjadikan perpustakaan-perpustakaan perguruan tinggi lebih memilih berlangganan jurnal elektronik dibandingkan dengan jurnal cetak dalam menunjang kegiatan penelitian organisasi induknya. Demikian pula dengan UPT Perpustakaan Universitas Hasanuddin.

UPT Perpustakaan Universitas Hasanuddin berlangganan database jurnal elektronik, yaitu Database ProQuest seharga 300 juta per tahun. Sebelumnya juga telah melanggan beberapa database jurnal elektronik, seperti Infotrac dan Ebscohost. Akan tetapi, 2 tahun terakhir ini sudah tidak berlangganan lagi dikarenakan kurangnya dana. Database jurnal elektronik Infotrac dan Ebscohost yang dilanggan oleh UPT Perpustakaan Universitas Hasanuddin Makassar sebelumnya dilanggankan oleh DIKTI akan tetapi, untuk database jurnal ProQuest dilanggankan oleh PT. Jasa Tama (Sumber: Pustakawan UPT Perpustakaan Universitas Hasanuddin).

E-Journal DIKTI atau Referensi Ilmiah Indonesia (RII) merupakan titik akses terhadap karya ilmiah yang dihasilkan oleh akademisi dan peneliti Indonesia, yang mencakup E-Journal Domestik, tugas akhir mahasiswa dan laporan penelitian. PTN atau PTS yang mendaftar nantinya akan mendapatkan Username dan Password yang bisa digunakan oleh sivitas akademika PTN atau PTS untuk mengakses berbagai jurnal yang telah dilanggan tersebut (Muin, 2014: 138).

Pemanfaatan koleksi jurnal elektronik hendaknya dibina dan disosialisasikan agar dapat dimanfaatkan secara maksimal. 
Pustakawan yang bertugas untuk mensosialisasikan keberadaan koleksi jurnal elektronik hendaknya mengetahui kendala serta tujuan yang akan dicapai dan siapa pemakai koleksi jurnal elektronik. Oleh karena itu diperlukan analisis kebutuhan pemustaka terlebih dahulu. Dengan cara mengenali pemustaka yang akan dilayani serta analisis koleksi dan evaluasi yang berguna untuk melihat apakah pemanfaatan koleksi tersebut telah sesuai dengan kebutuhan pemustaka.

\section{b. Rumusan Masalah}

1) Seberapa besar tingkat pemanfaatan jurnal elektronik oleh Mahasiswa(i) Fakultas Kedokteran Universitas Hasanuddin Makassar?

2) Kendala-kendala apa saja yang dialami oleh pemustaka dalam mengakses jurnal elektronik?

\section{c. Definisi Operasional dan Ruang Lingkup Penelitian}

Jurnal elektronik adalah jurnal yang segala aspek (penyiapan, review, penerbitan dan penyebaran) dilakukan secara elektronik. Kemunculan jurnal versi elektronik ini karena mahalnya pencetakan jurnal, kemajuan teknologi komputer dan meluasnya world wide web (Lasa HS, 2009: 128).

Objek dalam penelitian ini adalah mahasiswa Fakultas Kedokteran Universitas Hasanuddin Makassar. Adapun yang menjadi sampel dalam mengukur tingkat keefektifan pemanfaatan jurnal elektronik yang tersedia dalam database ProQuest yang dilanggan oleh UPT Perpustakaan Universitas Hasanuddin Makassar adalah Mahasiswa Kepaniteraan Klinik atau Mahasiswa Kedokteraan yang sedang melaksanakan COASS (Co-Assistant) angkatan 2011.

\section{d. Tujuan dan Manfaat Penelitian}

1) Tujuan Penelitian

a) Untuk mengetahui tingkat pemanfaatan jurnal elektronik oleh Mahasiswa Fakultas Kedokteran Universitas Hasanudin Makassar

b) Untuk mengetahui apa-apa saja kendala yang dialami oleh pemustaka dalam mengakses jurnal elektronik.

2) Manfaat Penelitian

a) Untuk menambah khazanah kajian ilmu perpustakaan, khususnya mengenai pemanfaatan jurnal elektronik oleh Mahasiswa Fakultas Kedokteran Universitas Hasanuddin Makassar.

b) Sebagai rintisan dan bahan perbandingan dalam rangka pengembangan penelitian berikutnya.

\section{KAJIAN PUSTAKA}

\section{a. Jurnal Online}

Peran jurnal online dalam pengembangan ilmu pengetahuan di era Google saat ini telah memberikan kontribusi yang besar bagi lembaga-lembaga pendidikan tinggi di tanah air. Ini telah menjadi kebutuhan utama pada tiap-tiap lembaga tinggi untuk menyediakan atau berlangganan jurnal-jurnal, baik dalam dan luar negeri, demi meningkatkan atau memperluas wawasan para civitas akademik.

Jurnal online atau yang biasa juga disebut dengan jurnal elektronik adalah jurnal yang menyajikan karya-karya ilmiah yang dapat diakses melalui jaringan komputer dan internet. Jurnal dari kata journal (Bahasa Perancis) berarti catatan peristiwa dari hari ke hari. Jurnal dari kata journei (Bahasa Inggris) berarti catatan sidang-sidang parlemen dari hari ke hari. Penggunaan kata jurnal untuk berbagai bidang juga membawa arti yang bervariasi. Misalnya jurnal dalam bidang ekonomi menunjukkan sistem pembukuan rangkap. Jurnal dalam bidang pelayaran 
diartikan sebagai logbook berarti buku untuk mencatat semua kejadian selama pelayaran (Lasa HS, 2009: 128).

Jurnal merupakan representasi dari pengetahuan baru tentang perkembangan ilmu pengetahuan yang dilaksanakan secara empiris dan biasanya merupakan gagasan yang terbaru. Sedangkan jurnal elektronik atau e-journal adalah jurnal yang segala aspek (penyiapan, review, penerbitan dan penyebaran) dilakukan secara elektronik (Nurochman, 2011).

Jurnal elektronik merupakan jurnal berbasis internet dimana proses persiapan, penerbitan dan publikasinya dilakukan secara elektronik. Dalam pengertian ini jurnal elektronik tidak ada bentuk tercetaknya, Prythrech dalam (Irianti, 2013).

\section{b. Pemanfaatan Jurnal Online}

Dalam dunia ilmu pengetahuan telah terjadi serbuan informasi dari para produsen informasi, berupa buku teks, jurnal, laporan penelitian, makalah seminar ilmiah, konferensi internasional maupun informasi yang dikemas secara elektronik (Sawitry, 2011: 30). Demikian juga dalam beberapa tahun terakhir ini, penelusuran informasi elektronik dan digital telah berkembang dengan sangat cepat, mulai dari koran, jurnal dan majalah ilmiah.

Pemanfaatan jurnal elektronik merupakan kegiatan atau aktivitas pemustaka dalam menggunakan jurnal dalam hal mencari informasi yang dibutuhkan yang dapat dimanfaatkan oleh pemustaka itu sendiri terhadap koleksi jurnal elektronik (Sawitry, 2011).

Pemanfaatan jurnal elektronik pada dasarnya merupakan layanan cyber dengan beragam informasi yang bersumber dari jaringan global, tentunya peran dari pustakawan sebagai penyaji informasi memerlukan keahlian khusus agar layanan tersebut berguna dan diminati oleh pemustaka. Pustakawan seharusnya memiliki strategi pemasaran digital untuk meningkatkan layananan dan pemanfaatan journal elektronik yang apabila berhasil melaksanakan strategi tersebut akan menciptakan ekosistem intelektualitas antara berbagai sumber-sumber informasi, pemustaka dan pustakawan (Nurochman, 2011).

Pemustaka lebih cenderung memanfaatkan jurnal online daripada jurnal tercetak, berikut ini tabel yang menunjukkan perbandingan antara kedua versi jurnal tersebut:

Tabel 1.

Perbandingan jurnal elektronik (online) dengan jurnal tercetak

\begin{tabular}{|c|c|c|c|}
\hline No & Kriteria & Elektronik & Tercetak \\
\hline 1 & Kemutakhiran & Mutakhir & Mutakhir \\
\hline 2 & $\begin{array}{l}\text { Kecepatan } \\
\text { diterima }\end{array}$ & Cepat & Lambat \\
\hline 3 & Penyimpanan & $\begin{array}{l}\text { Menghemat } \\
\text { tempat }\end{array}$ & Memakan tempat \\
\hline 4 & Pemanfaatan & 24 jam & $\begin{array}{l}\text { Terbatas jam buka } \\
\text { perpustakaan }\end{array}$ \\
\hline 5 & $\begin{array}{l}\text { Kesempatan } \\
\text { akses }\end{array}$ & $\begin{array}{l}\text { Bisa } \\
\text { bersamaan }\end{array}$ & Antri \\
\hline 6 & $\begin{array}{l}\text { Sarana } \\
\text { penelusuran }\end{array}$ & $\begin{array}{l}\text { Otomatis } \\
\text { tersedia }\end{array}$ & Harus dibuat \\
\hline 7 & $\begin{array}{l}\text { Waktu } \\
\text { penelusuran }\end{array}$ & Cepat & Lama \\
\hline 8 & Keamanan & Lebih aman & Kurang aman \\
\hline 9 & $\begin{array}{l}\text { Manipulasi } \\
\text { dokumen }\end{array}$ & $\begin{array}{l}\text { Sangat } \\
\text { mudah } \\
\text { (seperti: } \\
\text { kutipan dan } \\
\text { sebagainya) }\end{array}$ & Tidak bisa \\
\hline 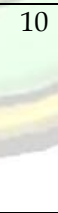 & $\begin{array}{lr}\text { Jumlah judul } \\
\text { yang dapat } \\
\text { dilanggan } \\
\text { dengan jumlah } \\
\text { dana yang } \\
\text { sama }\end{array}$ & $\begin{array}{l}\text { Judul bisa } \\
\text { lebih } \\
\text { banyak }\end{array}$ & Judul lebih sedikit \\
\hline 11 & $\begin{array}{l}\text { Harga total } \\
\text { langganan }\end{array}$ & $\begin{array}{l}\text { Jauh lebih } \\
\text { murah }\end{array}$ & Lebih mahal \\
\hline
\end{tabular}
Sumber: Adriaty (2006)

Jurnal online jika dilihat pada tabel di atas, memiliki banyak kelebihan dibandingkan versi tercetak untuk era saat ini. Sebagai contoh, cakupan jurnal online lebih luas dibanding yang tercetak. Artinya, sebagaimana yang telah dikemukakan sebelumnya bahwa siapa saja dapat 
memanfaatkan jurnal online tersebut selama terdapat jaringan internet. Namun demikian, terkadang juga ada beberapa jurnal online yang memiliki kebijakan mengenai siapasiapa saja yang dapat atau boleh untuk mengakses jurnal mereka. Seperti halnya beberapa jurnal online yang telah dilanggan oleh Fakultas Kedokteran Universitas Hasanuddin Makassar.

\section{METODOLOGI PENELITIAN}

\section{a. Jenis dan Pendekatan Penelitian}

Jenis penelitian ini adalah penelitian deskriptif dengan menggunakan pendekatan kuantitatif. Penelitian deskriptif yaitu penelitian yang dilakukan untuk menggambarkan kondisi nyata yang ada di lapangan atau objek penelitian tanpa ada usaha usaha lain seperti membandingkan dan mengevaluasinya. Pendekatan kuantitatif dilakukan mengingat penelitian ini menggunakan populasi dan sampel.

\section{b. Populasi dan Sampel}

Adapun yang menjadi populasi dalam penelitian ini yaitu Mahasiswa Kepaniteraan Klinik atau Mahasiswa Kedokteran yang sedang melaksanakan COASS (Co-Assistant) pada Fakultas Kedokteran Universitas Hasanuddin Makassar angkatan 2011. Berikut ini merupakan tabel populasi dan sampel pada penelitian kali ini.

Tabel 2.

Populasi Mahasiswa Kepaniteraan Klinik (Co-Assistant) angkatan 2011

\begin{tabular}{|c|c|c|c|}
\hline \multirow{2}{*}{ Program Studi } & \multicolumn{2}{|c|}{ Jenis Kelamin } & \multirow{2}{*}{ Jumlah } \\
\cline { 2 - 3 } & Pria & Wanita & \\
\hline Kedokteran Umum & 19 & 85 & 104 \\
\hline
\end{tabular}

Sumber: bagian akademik Fakultas Kedokteran Universitas Hasanuddin Makassar.

Teknik probably random sampling digunakan untuk menentukan sampel pada penelitian ini. Adapun besarnya sample yaitu
$25 \%$ dari total populasi, jadi yang menjadi sampel penelitian ini sebanyak 26 responden.

\section{c. Instrumen Penelitian}

Instrumen yang digunakan dalam penelitian ini berupa kuesioner/angket, yakni seperangkat pernyataan tertulis yang disediakan peneliti kepada responden untuk dijawab. Instrumen ini dibuat berdasarkan landasan teori atau variabel dalam penelitian ini.

\section{d. Teknik Pengumpulan Data}

Selain angket penelitian, penelitian ini juga menggunakan teknik observasi dan dokumentasi dalam mengumpulkan data. Observasi dilakukan sebagai kajian pendahuluan untuk mencari tahu apa-apa saja jurnal yang telah dilanggani oleh lembaga yang dimaksud, sementara dokumentasi digunakan untuk memperoleh gambaran umum mengenai jurnal online di Fakultas Kedokteran Universitas Hasanuddin.

\section{e. Teknik Analisis Data}

Skala Likert digunakan dalam penelitian ini. Jawaban setiap item instrumen yang menggunakan skala Likert mempunyai gradasi dari sangat positif sampai sangat negatif (Sugiyono, 2013: 96), dengan contoh sebagai berikut:

- Sangat Setuju dengan skor 5

- Setuju dengan skor 4

- Kurang Setuju dengan skor 3

- Tidak Setuju dengan skor 2

- Sangat Tidak Setuju dengan skor 1

Jawaban dari responden selanjutnya akan dikumpulkan dan diolah dengan menggunakan SPSS versi 21.0 dan seterusnya akan dideskripsikan satu persatu. Adapun data dalam penelitian ini dianalisis dengan menggunakan jenis statistik deskriptif dengan rumus sebagai berikut: 
Efektivitas $=\frac{a}{t}=1$

\section{Keterangan:}

$a=$ output nilai angket (data/nilai yang diperoleh dari angket)

$t=$ output nilai sampel (jumlah responden $\mathrm{x}$ bobot jawaban tertinggi)

1 = nilai efektif

Sumber: Sugiyono dalam (Nurwahidah, 2013: 39).

\section{HASIL PENELTIAN PEMBAHASAN}

DAN

\section{a. Hasil Penelitian}

1) Tingkat pemanfaatan jurnal elektronik oleh Mahasiswa(i) Fakultas Kedokteran Universitas Hasanuddin Makassar

Jurnal elektronik yang dilanggan oleh UPT Perpustakaan Universitas Hasanuddin Makassar diperoleh dari database Proquest yang berisi beberapa jurnal yang dapat diakses dan di download oleh para pemustaka. Semua angket yang disebarkan kepada para responden kembali dan terisi lengkap. Berikut ini akan dipaparkan satu persatu.

Grafik 1. Pemanfaatan jurnal elektronik untuk tugas perkuliahan

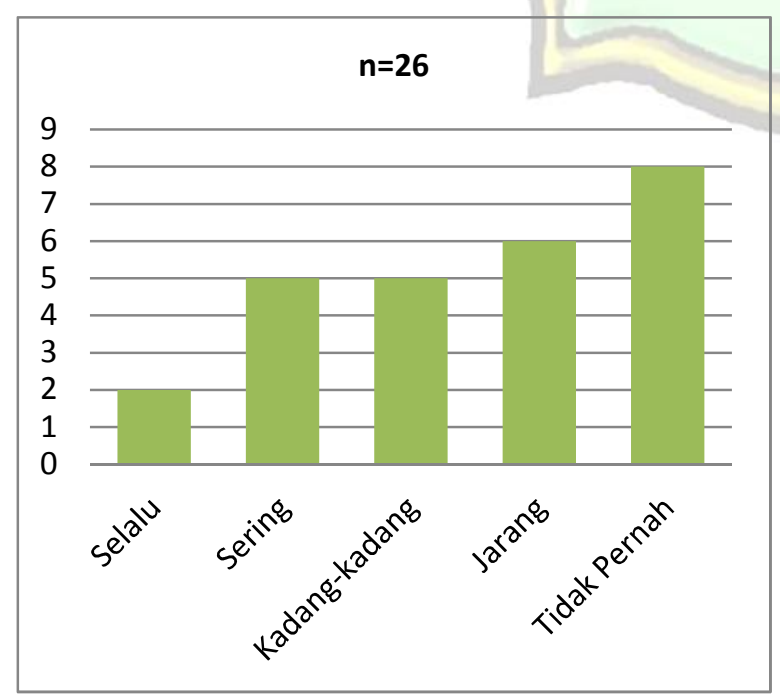

Gambar di atas menunjukkan tingkat pemanfaatan jurnal elektronik untuk penyelesaian tugas kuliah hampir sama rata. Dari grafik terlihat jumlah terbesar jawaban responden ialah tidak pernah memanfaatkan jurnal elektronik untuk menyelesaikan tugas kuliah.

Tabel 3.

Jurnal elektronik untuk bahan presentasi dan bahan penelitian

\begin{tabular}{|c|c|c|}
\hline No & Tanggapan Mahasiswa & $\begin{array}{c}\text { Jumlah } \\
\text { Responden }\end{array}$ \\
\hline 1. & Selalu & 3 \\
\hline 2. & Sering & 3 \\
\hline 3. & Kadang-kadang & 6 \\
\hline 4. & Jarang & 5 \\
\hline 5. & Tidak Pernah & 9 \\
\hline Jumlah & & 26 \\
\hline
\end{tabular}

Tabel di atas juga memberikan gambaran yang hampir sama dengan grafik sebelumnya, yaitu hampir setengah dari responden memberikan jawaban bahwa terkadang mereka memanfaatkan jurnal elektronik sebagai bahan presentasi dan bahan penelitian.

Tabel 4.

Jurnal elektronik mengandung informasi sangat lengkap dan mutakhir

\begin{tabular}{|c||c|c|}
\hline No & Tanggapan Mahasiswa & $\begin{array}{c}\text { Jumlah } \\
\text { Responden }\end{array}$ \\
\hline 1 & Sangat Setuju & 0 \\
\hline 2 & Setuju & 5 \\
\hline 3 & Kurang Setuju & 8 \\
\hline 4 & Tidak Setuju & 3 \\
\hline 5 & Sangat Tidak Setuju & 10 \\
\hline Jumlah & & 26 \\
\hline
\end{tabular}

Tabel di atas menunjukkan bahwa sebagian besar responden memberikan tanggapan bahwa kandungan informasi pada jurnal elektronik yang dilanggan oleh UPT Perpustakaan Universitas Hasanuddin masih kurang dan tidak mengandung informasi yang lengkap dan mutakhir. 
Tabel 5.

Jurnal elektronik menyediakan informasi sesuai dengan kebutuhan Mahasiswa(i)

\begin{tabular}{|c|c|c|}
\hline No & Tanggapan Mahasiswa & $\begin{array}{c}\text { Jumlah } \\
\text { Responden }\end{array}$ \\
\hline 1 & Sangat Setuju & 2 \\
\hline 2 & Setuju & 1 \\
\hline 3 & Kurang Setuju & 10 \\
\hline 4 & Tidak Setuju & 3 \\
\hline 5 & Sangat Tidak Setuju & 10 \\
\hline Jumlah & & 26 \\
\hline
\end{tabular}

Tabel di atas juga menggambarkan bahwa sebagian besar responden kurang setuju dan sangat tidak setuju bahwa informasi yang disediakan oleh jurnal elektronik sesuai dengan kebutuhan mereka.

Tabel 6.

Jurnal elektronik mudah diakses

\begin{tabular}{|c|c|c|}
\hline No. & Tanggapan Mahasiswa & $\begin{array}{c}\text { Jumlah } \\
\text { Responden }\end{array}$ \\
\hline 1 & Sangat Setuju & 1 \\
\hline 2 & Setuju & 6 \\
\hline 3 & Kurang Setuju & 4 \\
\hline 4 & Tidak Setuju & 5 \\
\hline 5 & Sangat Tidak Setuju & 10 \\
\hline Jumlah & & 26 \\
\hline
\end{tabular}

Berdasarkan tabel di atas, dapat dijelaskan bahwa sebagian besar responden menyatakan kurang dan tidak setuju bahwa jurnal elektronik yang dilanggan mudah untuk diakses.

Tabel 7.

Akses jurnal elektronik di kampus

\begin{tabular}{|c|c|c|}
\hline No & TanggapanMahasiswa & $\begin{array}{c}\text { Jumlah } \\
\text { Responden }\end{array}$ \\
\hline 1 & Selalu & 2 \\
\hline 2 & Sering & 2 \\
\hline 3 & Kadang-kadang & 8 \\
\hline 4 & Jarang & 5 \\
\hline 5 & Tidak Pernah & 9 \\
\hline Jumlah & & 26 \\
\hline
\end{tabular}

Dari tabel di atas menunjukkan bahwa sebagian kecil dari responden mengakses jurnal elektronik di area kampus, sementara sebagian besar lainnya kadang, jarang dan tidak pernah sama sekali mengakses jurnal di area kampus.

2) Kendala-kendala yang dialami oleh pemustaka (Mahasiswa Fakultas Kedokteran Universitas Hasanuddin) dalam mengakses jurnal elektronik.

Berdasarkan hasil penelitian yang diperoleh, maka ditemukan tiga kendala utama yang dialami mahasiswa dalam mengakses jurnal elektronik Proquest, yaitu sebagai berikut:

Tabel 8.

Jurnal elektronik tidak disosialisasikan kepada mahasiswa

\begin{tabular}{|c|c|c|}
\hline No & Tanggapan Mahasiswa & $\begin{array}{c}\text { Jumlah } \\
\text { Responden }\end{array}$ \\
\hline 1 & Sangat Setuju & 8 \\
\hline 2 & Setuju & 8 \\
\hline 3 & Kurang Setuju & 3 \\
\hline 4 & Tidak Setuju & 3 \\
\hline 5 & Sangat Tidak Setuju & 4 \\
\hline Jumlah & & 26 \\
\hline
\end{tabular}

Dari tabel di atas menggambarkan bahwa sebagian besar responden memberikan tanggapan setuju dan sangat setuju bahwa jurnal elektronik yang telah dilanggan oleh perpustakaan tidak disosialisasikan kepada mereka.

Tabel 9.

Bahasa Asing dalam Mengakses Jurnal Elektronik

\begin{tabular}{|c|c|c|}
\hline No & Tanggapan Mahasiswa & $\begin{array}{c}\text { Jumlah } \\
\text { Responden }\end{array}$ \\
\hline 1 & Sangat Setuju & 1 \\
\hline 2 & Setuju & 2 \\
\hline 3 & Kurang Setuju & 3 \\
\hline 4 & Tidak Setuju & 10 \\
\hline 5 & Sangat Tidak Setuju & 10 \\
\hline Jumlah & & 26 \\
\hline
\end{tabular}

Pada tabel di atas menunjukkan bahwa hampir seluruh responden menyatakan bahwa bahasa asing yang digunakan pada jurnal elektronik bukanlah menjadi kendala utama utama bagi mereka. 


\section{b. Pembahasan}

Keberadaan jurnal elektronik Proquest yang telah dilanggan oleh UPT Perpustakaan Universitas Hasanuddin Makassar tentu saja dimaksudkan agar para civitas kampus memiliki bahan bacaan yang bervariatif, tidak terfokus kepada bahan bacaan yang lain pada umumnya seperti buku, laporan, tesis, disertasi dan lain sebagainya.

Jurnal elektronik, sebagaimana yang telah dipaparkan sebelumnya bahwa dari segi kandungan informasinya mengandung karyakarya yang sifatnya mutakhir atau kontemporer masa kini. Dari jurnal, pemustaka akan menemukan penemuanpenemuan atau isu-isu terbaru dalam bidangnya masing-masing yang mana dalam penelitian ini lebih mengkhusus pada bidang Ilmu Kedokteran.

Tabel 10.

Akumulasi jawaban responden mengenai pemanfaatan jurnal elektronik

\begin{tabular}{|l|c|c|}
\hline \multicolumn{1}{|c|}{ Indikator Pertanyaan } & $\begin{array}{c}\text { Output } \\
\text { Aktual }\end{array}$ & $\begin{array}{c}\text { Output } \\
\text { Target }\end{array}$ \\
\hline $\begin{array}{l}\text { Pemanfaatan jurnal elektronik untuk } \\
\text { tugas perkuliahan }\end{array}$ & 65 & 130 \\
\hline $\begin{array}{l}\text { Pemanfaatan jurnal elektronik untuk } \\
\text { bahan presentasi dan penelitian }\end{array}$ & 64 & 130 \\
\hline $\begin{array}{l}\text { Jurnal elektronik sangat lengkap dan } \\
\text { mutakhir }\end{array}$ & 60 & 130 \\
\hline $\begin{array}{l}\text { Jurnal elektronik menyediakan } \\
\text { informasi yang sesuai dengan } \\
\text { kebutuhan }\end{array}$ & 60 & 130 \\
\hline Jurnal elektronik mudah diakses & 61 & 130 \\
\hline $\begin{array}{l}\text { Mengakses jurnal elektronik di } \\
\text { kampus TOTAL }\end{array}$ & $\mathbf{3 7 1}$ & $\mathbf{7 8 0}$ \\
\hline
\end{tabular}

Dari tabel akumulasi di atas, dapat disimpulkan bahwa tingkat pemanfaatan jurnal elektronik oleh mahasiswa Fakultas Kedokteran Universitas Hasanuddin Makasaar dapat dikategorikan 'Rendah'.

Adapun kendala-kendala yang ditemukan yaitu sosialisasi perpustakaan tentang jurnaljurnal dalam database Proquest belum optimal dilaksanakan oleh pustakawan. Meskipun demikian, hasil penelitian menunjukkan bahwa bahasa asing (Inggris) pada tiap-tiap jurnal yang ada bukanlah menjadi kendala utama bagi para mahasiswa Fakultas Kedokteran Universitas Hasanuddin Makassar.

Rendahnya pemanfaatan jurnal elektronik Proquest oleh para mahasiswa tentu saja merupakan hal yang perlu mendapat perhatian khusus oleh pengelola jurnal atau perpustakaan itu sendiri, mengingat alokasi dana yang disediakan untuk pengadaan (langganan) jurnal tersebut tidaklah murah.

Hemat peneliti, hal semacam ini tentu saja dapat dihindari jika dikaitkan dengan kendala-kendala yang ditemukan pada kajian ini. Promosi perpustakaan tentu memiliki peran yang sangat penting dalam hal ini. Pada bagian ini diharapkan pro aktif pustakawan dalam mensosialisasikan jurnal-jurnal yang ada di perpustakaan. Begitu pula dengan peran aktif pustakawan yang selalu diharapkan senantiasa memberikan layanan yang prima kepada para pemustakanya.

\section{KESIMPULAN DAN SARAN}

Dalam setiap penelitian tentu saja dapat ditemukan kekurangan-kekurangan atau kesalahan-kesalahan, begitu pula pada penelitian ini. Apa yang telah dipaparkan pada kajian ini merupakan gambaran faktual yang peneliti peroleh berdasarkan hasil jawaban responden di lokasi penelitian. Berikut ini merupakan kesimpulan dan saran pada penelitian ini.

\section{a. Kesimpulan}

1. Pemanfaatan jurnal elektronik oleh mahasiswa Fakultas Kedokteran Universitas Hasanuddin dapat dikategorikan 'Rendah'. Ini terbukti dari hasil jawaban responden sebesar 371 (idealnya yaitu 780, artinya semua responden memanfaatakan jurnal elektronik).

2. Adapun kendala-kendala yang dihadapi oleh mahasiswa Fakultas Kedokteran 
terhadap jurnal elektronik yaitu kurang optimalnya sosialisasi sehingga pengetahuan mereka tentang jurnal elektronik yang telah dilanggan kurang.

\section{b. Saran}

1. Diharapkan agar Perpustakaan Universitas Hasanuddin lebih memperkenalkan/mensosialisasikan jurnal elektronik yang telah dilanggan oleh perpustakaan dengan memberikan pengenalan rutin, ruangan/fasilitas khusus untuk mengakses langsung atau dengan berupa poster atau keterangan khusus tentang cara mengakses jurnal elektronik tersebut.

2. Diharapkan agar sosialisasi tentang pemanfaatan jurnal elektronik tidak hanya dilakukan pada saat penerimaan mahasiswa baru, akan tetapi dapat juga dilakukan menjelang akhir-akhir semester perkuliahan

3. Sosialisasi tentang pemanfaatan jurnal elektronik tidak hanya dilaksanakan di perpustakaan, tapi hendaknya dilaksanakan di setiap fakultas.

4. Sosialisasi tentang pemanfaatan jurnal elektronik juga dapat dilakukan melalui media sosial seperti facebook, twitter dan sebagainya.

5. Dari para responden mengharapkan agar perpustakaan dapat melanggan kembali jurnal elektronik Ebsco Host atau jurnal tentang kedokteran lainnya, seperti Pubmed, Medline, Healthscout dan sebagainya.

\section{DAFTAR PUSTAKA}

Adriaty, E. (2006). Pemanfaatan Jurnal Elektronis dan Kemutakhiran Informasi yang Disitir dalam Publikasi Primer. Jurnal Perpustakaan Pertanian, Vol. 14.

Arif Nurochman. (2011). Strategi Digital untuk Meningkatkan Pemanfaatan EJournal: Perspektif Pustakawan dan Perpustakaan. Jurnal Visi Pustaka, Vol.13, No.

HS, L. (2009). Kamus Pustakawan Indonesia. Yogyakarta: Pustaka Book Publisher.
Irianti, T. H. dan P. (2013). Pengaruh Aksesibilitas dan Ketersediaan Jurnal Elektronik terhadap Kepuasan Pengguna. Visi Pustaka, Vol.15, No.

Muin, M. A. (2014). Information Literacy Skills: Strategi Penelusuran Informasi Online. Makassar: Alauddin University Press.

Nurwahidah. (2013). "Efektivitas Pengelolaan Perpustakaan dalam Meningkatkan Layanan Pemustaka di Perpustakaan Sekolah Menengah Atas Negeri 1 Tinggimoncong Kabupaten Gowa". Skripsi. Makassar: UIN Alauddin.

Prahastuti, S. (2006). Pemanfaatan Jurnal Ilmiah Elektronik sebagai Sarana Komunikasi Ilmiah DikedeputianBidang Ilmu Pengetahuan Hayati-LIPI. Skripsi. Jakarta: Universitas Indonesia.

Republik Indonesia. (2014). Peraturan Pemerintah Republik Indonesia Nomor 24 Tahun 2014 tentang Pelaksanaan Undangundang Nomor 43 Tahun 2007 tentang Perpustakaan.

Sawitry, N. D. (2011). Pemanfaatan Koleksi EJournal Bidang Ekonomi dan Bisnis oleh Civitas Akademika pada Perpustakaan Fakultas Ekonomi dan Bisnis (FEB) UIN Syarif Hidayatullah Jakarta. Skripsi. Jakarta: UIN Syarif Hidayatullah.

Shihab, M. Q. (2002). Tafsir Al-Mishbah: Pesan, Kesan dan Keserasian al-Qur'an. Jakarta: Lentera Hati.

Sugiyono. (2013). Metode Penelitian Kuantitatif, Kualitatif dan RED. Bandung: Alfabeta.

Supriyanto, A. M. dan W. (2012). Teknologi Informasi Perpustakaan: Strategi Perancangan Perpustakaan Digital. Yogyakarta: Kanisius.

Widi, R. K. (2010). Open Journal Sistem (OJS) untuk Mengelolah Jurnal Ilmiah. Jurnal Perpustakaan Indonesia, Vol.10, No. 